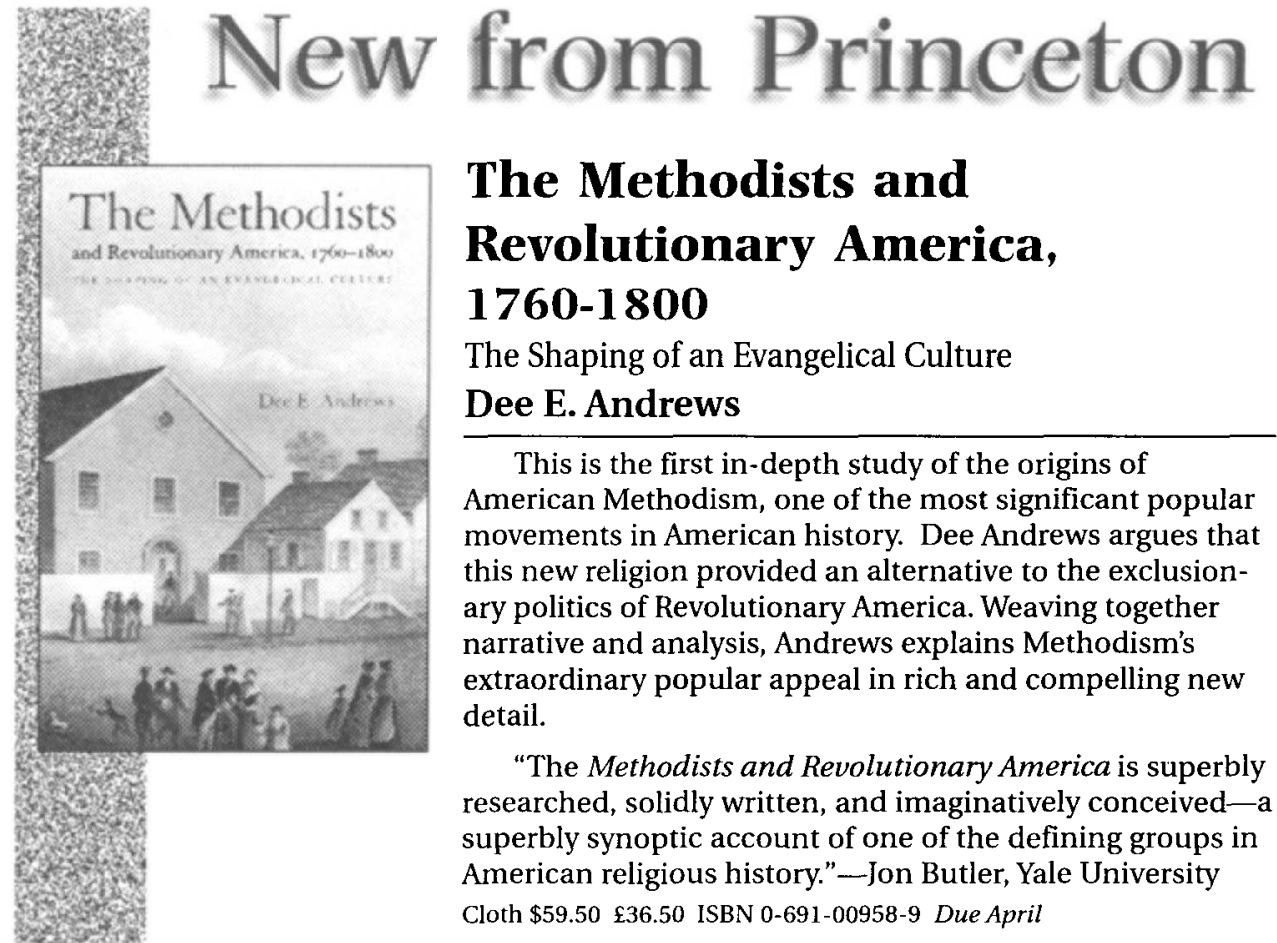

Expanded paperback edition

\title{
The Philosophical Theology of Jonathan Edwards
}

\author{
Sang Hyun Lee
}

This book demonstrates the originality and coherence of Jonathan Edwards's philosophical theology by using his dynamic reconception of reality as the interpretive key. This expanded edition includes a new preface and a new appendix titled "Jonathan Edwards on Nature."

"[An] enduring contribution to our understanding of the essential features of Edwards's thought. [Lee's] is a bold and daring work in a way appropriate to the boldness of Edwards himself."-Roland A. Delattre, Religious Studies Review

Paper \$18.95 E11.95 ISBN 0-691-04942-4 Due March

\section{Princeton University Press}

AT FINE BOOKSTORES OR CALL 800-777-4726 • WWW.PUP.PRINCETON.EDU 

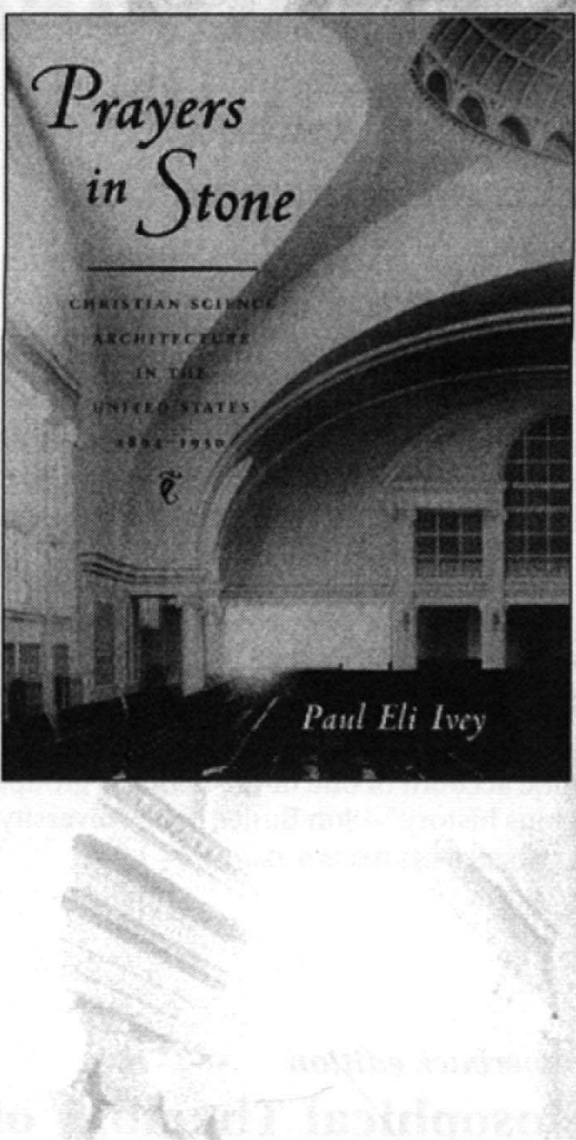

New in the series Illinois Medieval Studies

\section{Prayers in Stone}

Christian Science Architecture in the

United States, 1894-1930

PAUL ELI IVEY

"A significant piece of original scholarship, an extremely interesting study ... for those studying religious and civic architecture. ... There is simply nothing else like it." Peter W. Williams, author of Houses of God 86 photos. Cloth, $\$ 49.95$

\section{The Theodore Psalter}

(electronic facsimile)

\section{EDITED BY CHARLES BARBER}

Provides a complete display of all 416 pages of this Byzantine masterpiece, with magnified views of every illustration. The text is fully searchable in the original Greek and in English translation, and has hyperlinked descriptions and full identifications of figures on every page.

CD-ROM with booklet, $\$ 75.00$

Publisbed in association with the Britisb Library
Book and Verse

A Guide to Middle English Biblical Literature JAMES H. MOREY

The first comprehensive catalog of Middle English biblical literature and an indispensable guide to the variety and extent of biblical literature in England.

Cloth, \$34.95 Supported by Emory University Gradwateschool

\section{Byzantine Jists}

Errors of the Latins

TIA M. KOLBABA

This pathbreaking work examines the lists compiled by Byzantine Christians of the "errors" of Latin Christians. The author presents an explanation of their significance that is both erudite and eminently readable. Cloth, $\$ 34.95$ 


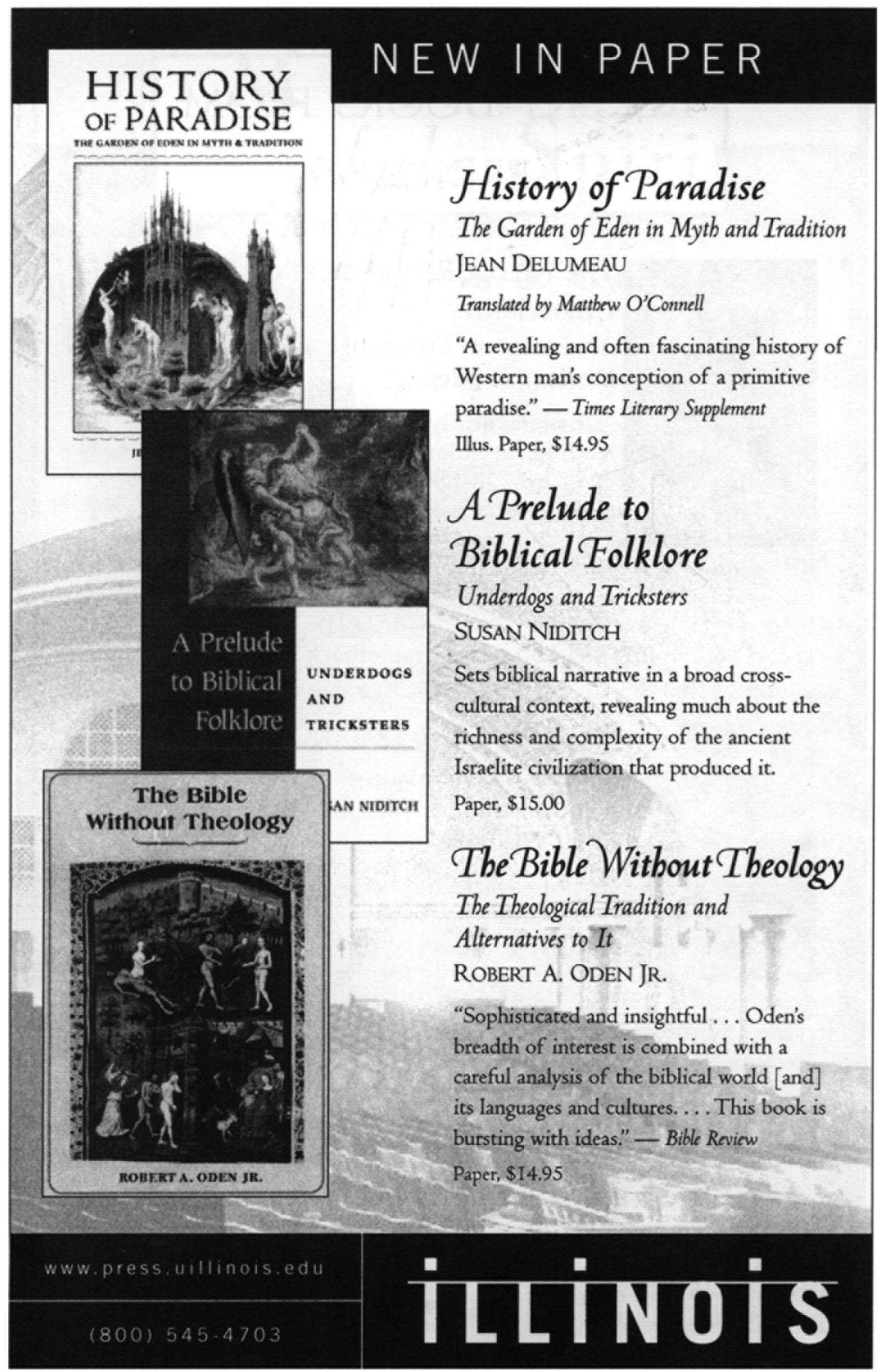




\section{RECENT BOOKS FROM EERDMANS}

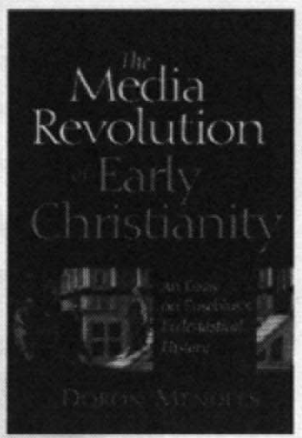

\section{The Media Revolution of Early}

CHRISTIANITY

An Essay on Eusebius's Ecclesiastical History Doron Mendels

"This new study by Doron Mendels, one of the leading historians of antiquity in Israel today, gives new insights into the work of Eusebius, the earliest Christian history writer after Luke.... That this book comes from the pen of a Jewish historian of antiquity makes it especially attractive, not only for Christian readers but also for a broad readership interested in the history of the ancient world." - -MARTIN HENGEL ISBN 0-8028-4610-6 $\cdot 280$ pages · paperback $\cdot \$ 24.00$

RETRIEVING THE TRADITION AND RENEWING
EVANGELICALISM
A Primer for Suspicious Protestants
D. H. Williams
This one-of-a-kind book is meant to help
Protestant Christians read and receive the early
church fathers as an essential part of their faith.
Written primarily for the evangelical, indepen-
dent, and free church communities, who remain largely suspi-
cious of church history and the relationship between Scripture
and Tradition, Retrieving the Tradition and Renewing Evangelicalism clearly
explains why every branch of today's church is indebted to the
doctrinal foundation laid by postapostolic Christianity.
ISBN 0-8028-4668-8 $\cdot 253$ pages · paperback $\$ \mathbf{~} \mathbf{1 6 . 0 0}$

At your bookstore, or call 800-253-7521 Fax: 616-459-6540 E-mail: sales@eerdmans.com 9555 WM. B. EerdMANS 255 JEFFERSON AVE. S. E. / GRAND RAPIDS, MI 49503 


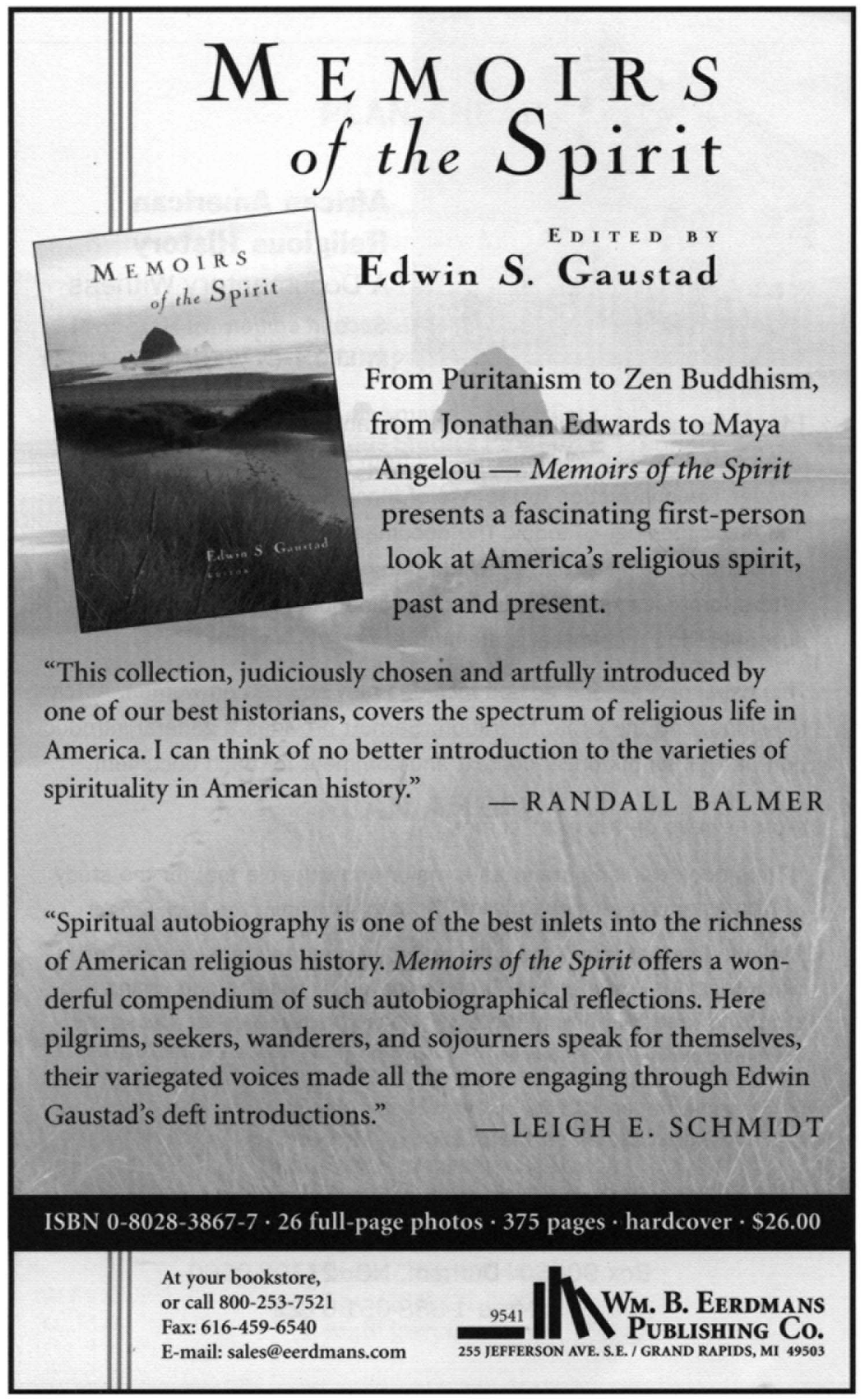




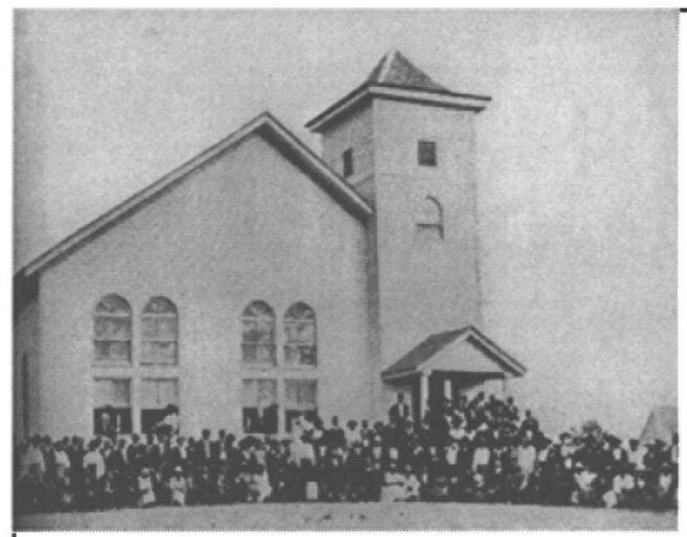

\section{African American Religious History}

\section{A Documentary Witness}

\section{Second edition}

MILTON C. SERNETT, EDITOR

This widely-heralded collection of remarkable documents offers a view of African American religious history from Africa and early America through Reconstruction to the rise of black nationalism, civil rights, and black theology of today. The documents-many of them rare, outof-print, or difficult to find-include personal narratives, sermons, letters, protest pamphlets, early denominational histories, journalistic accounts, and theological statements.

This expanded second edition includes new sources on women, African missions, and the Great Migration. Sernett provides a general introduction as well as historical context and comment for each document.

FROM REVIEWS OF THE FIRST EDITION

"[T]his book will long stand as a major and valuable tool for the study of Afro-American religious history." -Sandy D. Martin, The Black Scholar "Anyone interested in America's religious past and, specifically, the black religious experience will be rewarded by reading and urging others to read this fine anthology."-Robert Michael Franklin, Journal of the American Academy of Religion

576 pages, paper $\$ 23.95$

C. Eric Lincoln Series on the Black Experience

\section{Duke University Press}

Box 90660 Durham, NC 27708-0660

toll-free 1-888-651-0122 


\title{
PLAN AHEAD
}

\author{
Winter Meeting \\ 4-7 January 2001 \\ Boston, Massachusetts
}

Proposals for papers and sessions are welcomed by the Program Committee. Send abstracts of papers and CVs of all participants to:

$$
\begin{gathered}
\text { Professor Amanda Porterfield } \\
\text { Religious Studies Program } \\
\text { University of Wyoming } \\
\text { Laramie, WY 82071 } \\
\text { E-mail: ap@uwyo.edu } \\
\text { Phone: (307) 742-7543 }
\end{gathered}
$$

Deadline for submitting proposals: 15 April 2000

\section{PLAN AHEAD}

\author{
Spring Meeting \\ 29-31 March 2001 \\ Yale University
}

Proposals for papers and sessions are welcomed by the Program Committee. Send abstracts of papers and CVs of all participants to:

\section{Professor Harry S. Stout}

The Institute for the Advanced Study of Religion at Yale Whitney Humanities Center

$$
53 \text { Wall Street }
$$

New Haven, CT 06520

Phone: (203) 432-4040

Fax: (203) 432-1087

E-mail: iasry@yale.edu 


\section{ASCH IS NOW ON THE WEB}

- Obtain information about membership and subscriptions

- Confirm dates and places of future meetings

- Learn criteria for submissions to Church History

- Verify requirements and deadlines for prizes

- Place announcements about calls for papers, grants and competitions, personal items, etc., in our Newsletter

- Enter your own questions, responses, professional concerns, etc., on our Bulletin Board

- Plus other features to aid your search

Visit us at www.churchhistory.org 


\section{Awards of the American Society of Church History:}

The Frank S. and Elizabeth D. Brewer Prize, offered annually, is a subvention fund of $\$ 1,000$ to assist a press in publishing a book-length manuscript in church history. The prize is limited to first books. The monetary grant will be made upon receipt of a commitment in writing from a publisher accepting the manuscript. Entries in their final form must be received by 1 November.

The Albert C. Outler Prize is an award in the amount of $\$ 1,000$ to the author of the best book published in the two previous calendar years in ecumenical church history. "Ecumenical" is to be construed as concerned chiefly with problems of Christian unity and disunity (doctrinal, cultural, institutional) or with interactions between Christianity and other religious movements in any historical period. Authors of eligible books or any member of the Society may nominate titles for consideration; authors should submit a copy of the book. Nominations must be received by 1 March in even-numbered years.

The Philip Schaff Prize is an award in the amount of $\$ 1,000$ to the author of the best book published in the two previous calendar years, originating in the North American scholarly community and presenting original research on any period in the history of Christianity. Authors of eligible books or any member of the Society may nominate titles for consideration; authors should submit a copy of the book. Nominations must be received by 1 March in odd-numbered years.

The Jane Dempsey Douglass Prize is an annual award in the amount of $\$ 250$ for the author of the best essay published during the previous calendar year on any aspect of the role of women in the history of Christianity. Authors of eligible articles and any member of the Society may nominate titles for consideration. Nominations, accompanied if possible by a copy of the article, must be received by 1 August.

The Sidney E. Mead Prize, offered annually, is an award in the amount of $\$ 250$ for the author of the best unpublished essay in any field of church history written by a doctoral candidate or recent graduate whose manuscript stems directly from doctoral research. The manuscript will be published in Church History. Entries of no more than twenty-five double-spaced pages, including double-spaced endnotes, must be submitted by 1 July.

A work may be submitted for only one ASCH competition. For more information, or to nominate a book or submit a manuscript, write to the American Society of Church History, P.O. Box 8517, Red Bank, NJ 07701. 
Church History: Studies in Christianity and Culture is published four times per year (March, June, September, and December) by the American Society of Church History. Membership dues for individuals are $\$ 40$ per year for regular membership, $\$ 20$ per year for retired persons who previously held regular membership for at least five years; and free for two years for graduate students with the approval of a professor who is a member of the Society (after two years, graduate students pay $\$ 20$ annually until graduation). Institutional subscriptions are $\$ 50$ per year. Foreign postage is an additional $\$ 10$ per year. Single issues are $\$ 15$. Please make remittances payable to "American Society of Church History."

Office of the executive secretary: American Society of Church History, P.O. Box 8517, Red Bank, NJ 07701-8517.

Subscription applications, renewals, changes of address, claims for missing numbers, orders for single copies of current or back issues, and requests for permission to quote should be sent to the executive secretary. Claims for missing numbers will be honored without charge if made within two months of the regular month of publication.

Microfilm reproductions of The American Society of Church History Papers, series I and II, and of Church History, volumes 1-17 (1932-48), are available from the ATLA Preservation Board. Orders for these reproductions as well as inquiries about microfilm portions and photocopies should be sent to 1118 East 54th Place, Chicago, IL 60615.

Microfilm reproductions of Church History starting with volume 18 (1949) are available to subscribers and members of the Society from University Microfilms, 300 North Zeeb Road, Ann Arbor, MI 48106. The full text of Church History is also available in the electronic versions of the Humanities Index. Church History is indexed in Religion Index One: Periodicals, Index to Book Reviews in Religion, Religion Indexes: RIO/RIT/IBRR 1975- on CD-ROM, and ATLA Religion Database on CD-ROM, all published by the American Theological Library Association, 820 Church Street, Suite 400, Evanston, IL 60201-5613; (888) 665-ATLA; atla@atla.com; http://atla.library.vanderbilt.edu/atla/ home.html.

The following indexes are available from the office of the executive secretary: volumes 31-39 (1962-1970), volumes 40-49 (1971-1980), vols. 50-59 (1981-1990). Each index costs \$15. Book reviews are indexed or abstracted in Book Review Index, Historical Abstracts, and America: History and Life.

Editorial office: Church History, The Divinity School, Duke University, Box 90975, Durham, NC 27708-0975; (919) 660-3470; fax (919) 660-3473; church-history@duke.edu.

Send manuscripts, books for review, and requests about advertising to the editorial office. Manuscripts should run 6,000-11,000 words (or approximately 20-35 pages), not including endnotes, and should be printed double-spaced in 11-or 12-point font; endnotes must be printed double-spaced on separate pages following the text. The editors request (1) three copies of the manuscript (in order to protect the author's anonymity during the review process, the author's name should appear only on the title page of the essay); (2) three copies of a 200-word abstract (if Church History publishes the essay, the abstract may be printed above the first line of the text of the article and/or it may be included on the forthcoming Church History webpage); (3) a 31/2-inch diskette containing the manuscript and abstract (instead of sending a diskette, you may submit your manuscript and abstract by electronic mail). Further guidelines are available on request.

Church History is printed by the Science Press division of Mack Printing Group, Ephrata, Pennsylvania. Periodicals postage paid at Red Bank, New Jersey and additional mailing offices. Postmaster: Send address changes to American Society of Church History, P.O. Box 8517, Red Bank, NJ 07701.

\section{CHURCH History (ISSN 0009-6407)}

The opinions expressed in this journal represent the views only of the individual contributors; they do not necessarily reflect the views of the editors, Duke University, or the American Society of Church History. Advertising in Church History does not necessarily imply endorsement. 


\section{CONTENTS}

1 Forging Papal Authority: Charters from the Monastery of Montier-en-Der

Constance B. Bouchard

18 "We Speak to God with our Thoughts": Abelard and the Implications of Private Communication with God Susan R. Kramer

41 Audacious Nuns: Institutionalizing the Franciscan Order of Saint Clare Lezlie Knox

63 Retelling the History of the Early Church: Erasmus's Paraphrase on Acts Hilmar M. Pabel

86 Antiguan Methodism and Antislavery Activity: Anne and Elizabeth Hart in the Eighteenth-Century Black Atlantic John Saillant

116 A Political Factor in the Rise of Protestantism in Korea: Protestantism and the 1919 March First Movement Timothy S. Lee

143 Book Review Forum

150 Books 